tion of the sick poor in the immediate vicinity, and of those suddenly seized with sickness or maimed by accident. It is one of the essential conditions of usefulness for such an institution that it be located in a populous district such as the Builder deprecates. We are not disposed to insist upon the propriety of retaining St. Thomas's Hospital on its present site, seeing that it has so important a neighbour as Guy's in such close proximity; but it is certain that if it is intended to retain the character of an hospital for acute medical and surgical dis orders, such as it at present has, that character would be lost by removal to a distant, though accessible, suburb.

\section{ST. GILES'S AND ST. GEORGE'S.}

THE history of sanitary progress in the various districts of London is a subject that might form an interesting study for any sanitarian of archæological tastes, and the late publications under the authority of the Master of the Rolls offer abundant materials for particular illustration. Dr. Buchanan, the Medical Officer of Health for the St. Giles's district, presented some interesting points in the sanitary history of the parishes of St. Giles and St. George in the course of a lecture which he recently delivered. Since the days of Elizabeth, St. Giles has always been the patron saint of a crowded population, who died off at a much more rapid rate than those who lived in happier localities. The parish has always been densely inhabited, and from the time of the earliest census an excess in the mortality has always been maintained. It was in this parish that the great plague of 1665 first broke out, and two-thirds of the poorer inhabitants were destroyed in the year. The addition of the prosperous suburb of Bloomsbury lightened the death-rates, but they still retained their evil pre-eminence compared with other districts. The moral was plain enough. The mortality has always been highest in the most crowded districts. Sanitary improvements have never failed to produce a corresponding amelioration in the tables of mortality and disease; and Dr. Buchanan was able to show that, from mere drainage improvements, for instance, in Dudley-street, the deaths from fevers and other zymotic diseases had fallen in 1858 to exactly one-half the number in 1857 . In the whole district there were last year fewer deaths than the average by 120, although the year was much less healthy than its predeeessor.

\section{THE SOCIAL EVIL IN THE CAMP.}

THE correspondence just published of Napoleon I, contains an order of the day, issued in Italy, which shows with how strong a will he dealt with the abandoned women who followed the army, and incited the soldiers to every kind of vice, riot, and disorder. The order was to this effect:- "All women who have not the permission of the commissariat are required to leave the division in twenty-four hours: in default of doing so they will be arrested, smeared over with black, and exposed for two hours in the public square. The General-in-Chief is informed that the disorders which prevail are attributable to these abominable women." Looking to recent sad and difgraceful events at the Aldershott camp, we can but think that this order might afford a most useful hint to the General commanding there. The most disgraceful licentiousness prevailed in the outskirts of the camp. Certainly if it is anywhere possible to check the evils of disordered and vicious prostitntion, it is in a home encampment such as we have there, where strict military rule prevails, and where salutary measures are not the less easy to enforce because arbitrary and decisive. The public scandal of the state of things recently made known; the disease, the vice, and the disorder occasioned by an entourage so degrading and so morbific, may with facility be caused to cease; and we earnestly hope that the military authorities will enforce the abolition of a scandalous and impolitic licence which public opinion loudly condemns.

\section{MEDICO-PARLIAMENTARY.}

Commons. - Friday, March 11th.-The Solicitor-General gave notice that he would move for leave to bring in a Bill to amend the Law on Commissions of Lunacy.

Saturday, March 12th.-Mr. Monsell called attention to the increasing mortality from small-pox which now prevailed in no less than twenty-seven counties of England, and throughout Wales. He wished to know what steps had been taken by the Privy Council in exercise of their powers in the matter of vaccination.

Mr. Adderley said that the Privy Council were active in exerting their powers. They had issued regulations to the boards of guardians requiring that vaccinators should be on the Register under the Medical Act; they had drawn up recommendations for the more successful practice of vaccination, which would be forwarded; and were about to obtain returns showing the successful cases of vaccination from each board of guardians. When any considerable discrepancy was found, on comparing these with the number of births, inspectors would be sent down to trace out the cause of the neglect, and to remedy it. Finally, a report would be duly made to Parlia. ment of what was done, upon which judgment might be delivered.

Monday, March 14th. - Mr. Williams asked the hon. member for Bath what steps had been taken by the Metropolitan Board for the main-drainage of London, particularly on the south side of the river.

Mr. Tite gave a detailed account of the present state of the works. There were three systems of sewers intended on the north, and two on the south side of the river. The two on the south side would flow into the estuary of the Thames at Erith; the three on the north side would run into the sea at Barking Creek. The works would, it was hoped, be completed in four years: the sum required was $£ 3,000,000$, raised on loan from the Bank of England, and to be paid off in forty years by a $3 d$. rate on the metropolis.

Tuesday, March 15th.--The Medical Act (1858) Amendment Bill was read a second time.

Wednesday, March 16th. - On the motion for going into Committee on the Lunatic Poor (Ireland) Bill, Col. Greville moved that the Bill be committed that day six months. He objected to the transference of power to a Board of Visitors elected by grand juries, and complained that the whole maintenance of the lunatic poor would be thrown on the ratepayers, who at present paid only a half. After much discussion, in which Lord Naas, Mr. Brady, Mr. Osborne, and others took part, the Bill was referred to a Select Committee, on the motion of $\mathrm{Mr}$. J. D. Fitzgerald.

On the motion of Mr. Slaney, the Recreations-Ground Bill was read a third time, and passed.

\section{UัUนxนspondenet. \\ "Audialteram partem."}

\section{THE TOMB OF HARVEY. (LETTER FROM DR. TYLER SMTTH.) \\ To the Editor of THE LANCET.}

SIR, - The profession owe a debt of gratitude to Mr. Buck. land, for his watchful care in searching, through several days, in the vaults of St. Martin-in-the-Fields, for the remains of John Hunter. But for this, the coffin would probably have been removed, and all traces of its identity lost. The Council of the College of Surgeons have since determined to re-inter their great chief in Westminster Abbey, and this has mooted the question of removing the remains of Harvey from their present resting-place. 
In June, 1846, I made a visit to the tomb of Harvey at the village church of Hempstead, in Eissex. At the time, I published some particulars in THE LANCET, and deplored the in. difference and want of respect shown by the profession for its illustrious dead. I now venture to add some further recollections, in the hope that the Fellows of the College of Physicians may be led to consider whether the coffin of Harvey should not be borne to Westminster to rest with that of Hnnter.

On the occasion referred to, I got out at the Elsenham Station of the Eastern Counties Railway, and walked through a pleasant country by way of Thaxted, to Hempstead. The family vault of the Harveys lies immediately under the site of the family pew, which must have been placed in the most honourable position in the church. The decorated seats of the pew have been allowed to fall to pieces, and were lying together as rubbish, in a corner. The pew is raised above the floor of the rest of the church, and the entrance to the vault is by a wooden trap-door, which was without any lock or fastening. The floor of the pew forms the roof of the vault, and the latter, in consequence of the elevation of the pew, is only partially under ground. There is an open window, without any adequate protection beyond a rusty iron bar, looking from the vault into the churchyard. The coffin of the immortal discoverer of the Circulation of the Blood was easily recognised by the name or initials engraved on the lid. It is of lead, yet not so heavy but that it could be easily lifted. The person who showed me over the vault rattled the bones, apparently as part of the exhibition. The coffin can be seen through the open window, and might at any time have been stolen without difficulty.

There was no want of respect or reverence on the part of the College of Physicians at the time of Harvey's death. His body was taken from the old college in Ave Maria-lane, and attended to Hempstead-then, probably, a two days' journey -by "as many of the Fellows as were able." Aubrey describes how himself and his friends "helpt to carry him into the vault." A handsome monument, surmounted by a fine marble bust, was placed over the vault by the College soon after his death; ard subsequently the large quarto edition of his works was published at the charge of the College.

In seven years from the present date, the bi-centenary of the death of Harvey will arrive. It is chiefly the altered circumstances of the times, which make it a matter of irreverence and neglect that the remains of Harvey should continue in the state in which they now are. Westminster Abbey, two centuries ago, had not become a national mausoleum. The last male descendant of the Harveys, Admiral Sir Eliab Harvey, who commanded "the fighting Temeraire" at the battle of Trafalgar, died in 1816; and unless the College of Physicians should interfere, there is now, apparently, no one on whom devolves the duty of caring for the dust of the greatest man which medicine has ever produced.

I am, Sir, your obedient servant,

Upper Grosvenor-street

W. TYLER Sirthe, M.D. March, 1859.

\section{THE ARMY VERSUS INDIAN MEDICAL SERVICE.}

To the Editor of THE LANCET.

SIR,-In The LANCET of the 12th instant, there appear in your columns no less than three letters, evidently from medical officers of the Indian Forces, contrasting their position and advantages with those enjoyed by their brethren of the Royal Army; and as this subject has now assumed some im portance, perhaps you will allow me to offer a few additional observations.

"Tôba" considers that, in the year 1855, " the Indian me dical service was the first in the world ;" but, alas ! according to his view, those halcyon days have passed, for he emphatically indites "it is not so now." "A Medical Officer" asserts (what no one doubts) that " the surgeons in the Indian Army are second to no others in the conscientious discharge of onerous duties;" then naively assures us, "they wait for a sign;" and concludes with asking " if nothing is to be done to place these meritorious officers on a par with their brethren of the other services." Last in array comes "Quid pro Quo," who dates from the sultry shores of Bombay.

Now, this latter correspondent's letter is so partial, so biassed, and so calculated to mislead-his prospectus of grievances is of so expansive a character-his knowledge of the facts he alleges is so thorough and ample, that it really requires some time to appreciate the disinterested frankness which induced him-writing, too, from the far East-to undertake a gratuitous and weary task. "Quid pro Quo" is candid to a fault. He " begs to draw the attention of medical students and their friends to the so-called 'adrantages' of the Indian medical service." The aspirant is required to pass a very difficult examination. He has to pay his own passage to India, and, on arrival, is attached to some regiment. Shortly afterwards, he has to march hundreds of miles on detached duty. Pay does not cover expenses. In a few years, however, he gets a regiment, and remains on the pay of $£ 358$ to $£ 383$, according to the distance he happens to be from the Presidency, till he has served ten years. Promotion, continues "Quid pro Quo," takes place in from fifteen to seventeen years, and the pay is then enough (we are cheerily told) to support co single man; " but you must not marry," for that, says "Quid pro Quo," in the tone of a man enunciating a great fact, "is little better than beggary!" "These things," severely writes your judicious correspondent, "are not found out till the assistant-surgeon has been in India;" still (and this is reassuring) he "thinks, on the whole, a medical officer may manage to live without getting into debt." But to make the Indian service worth entering, there are several requirements: increased pay, augmented rank, quicker promotion, furloughs after seven years, and retiring allowances for which you should only pay about the same as in an assurance office. "I hese little concessions made, "Quid pro Quo" flatters us that " the Indian service might be worth the attention of the best men from our schools and colleges;" but, under the present conditions, he thinks "the Royal medical service is infinitely preferable."

It is far from my desire to introduce acerbity into this correspondence; but I am bound to observe that "Quid pro Quo" is either very ignorant, or greatly careless of facts. I do not, however, charge him with deliberate misstatement, but merely intend to demonstrate to you that, though there is some truth amid the long array, consisting of no less than twenty counts, which he marshals as "grievances" around us, still it would be well that "medical students and their friends" should understand that the entire facts concerning the Indian medical service have been but partially laid before them.

With your permission, Sir, I purpose in this communica. tion cursorily, yet I trust in a sufficient manner, to investigate the various complaints of your correspondents, as I think this matter requires ventilation, and it is advisable that the profession should comprehend the grounds upon which "agitation" is based.

1st. There is, no doubt, one great disadvantage on the Bombay side; for assistant-surgeons are obliged-unless they have interest sufficient to enable them to avoid the distasteful duty -to serve for two years in the Indian flotilla, and certainly the Persian Gulf is scarcely paradise. During this time, however, they get 300 rupees per mensem, or $£ 360$ a year. I will now. just glance almost seriatim at the more pertinent statements of "Quid pro Quo."

2nd. It is true enough, and can scarcely be thought a hard. ship, that, on first appointment, a young medical officer has to pay his own passage to India; this, if he goes by long sea, should not cost him more than $\mathfrak{E} 60$. But if he is fortunate, he may very possibly obtain medical charge of troops, as the India House gives the preference, supposing the other claims are about equal, to officers attached to its service. If he is appointed to such a duty, he gets a free passage and head money, according to the rumber of troops landed in India. "Capital required," says "Quid pro Quo," at "least $£ 320$." I scarcely see this. Take the contingency that the assistant-surgeon cannot obtain troops. How do matters stand? The India House advances him 120 days' pay, about $£ 100$; passage costs $£ 60$; uniform, \&c. $£ 100$; horse and camp equipage, $£ 60,=£ 220$. deduct as advanced, $£ 100$ : total capital required, $£ 120$.

3rd. "He is shortly required to march hundreds of miles on detached duty. Pay does not cover expenses." When sent on detachment duty, a distance of 200 miles, the medical officer gets "full" batta, instead of " half," and head money per month for the troops. Detaclement duty is generally remunerative. The expenses of living on a march are less than in cantonments; and there is neither house rent nor the expenses of mess to be paid, whilst the head money is a clear gain. The only real expense in marching is for "carriage," and this seldom amounts to as much as the monthly hire of a bungalow.

4th. "In the course of a few years, he gets charge of a regiment, and remains on this rate of pay till he has served 